\title{
陶磁器用粘土の分類と評価 一一特に含水系を中心にして一
}

\author{
芝崎靖雄・前田武久・渡村信治
}

(名古屋工業技術試験所)

可塑性粘土とその構成鉱物との関係を明らかにする目的で, 日本の陶磁器素地に用いられている 20 種の粘土について, 鉱物種の同定と可塑性の測定を行った. 構成鉱物種の組み合わせから，堆 積成因のもので，(1)モンモリロナイトを含む木節粘土系，(2)モンモリロナイトをほとんど含まない 木節粘土系，(3)有機物とモンモリロナイトをほとんど含まない蛙目粘土系に，熱水成因のもので， (4)カオリナイトを含む混合層粘土系，(5)カリナイトを含むセリサイト質粘土系，の五つに分類し た.

一方，粘土粉体から比表面積，Ig. loss を，また，Pfefferkornの可塑性試験法から粘土（練土） の含水量を測定し, 可塑含水率, 保水率, 可塑特性値及び粘土粒子表面の水膜の厚さをそれぞれに 算出した．これらの可塑性表示法の中で，可塑特性値による粘土の分類と鉱物的な分類が最もよく 一致した.この可塑特性值は，また，従来から可塑性の指標と言われている水膜の厚さよりも，可 塑性の表示法としてはるかに優れていることを明らかにした.

(1983 年 7 月 29 日受付)

\section{Classification of Clays for Ceramic Bodies by Water Content}

\author{
Yasuo SHIBASAKI, Takehisa MAEDA and Shinji TOMURA \\ $\left(\begin{array}{l}\text { Government Industrial Research Institute, Nagoya } \\ 1-1, \text { Hirate-cho, Kita-ku, Nagoya-shi }\end{array} 62\right.$ )
}

To clarify the relation between constituent minerals and plasticity of clays, identification of constituent clay minerals and measurement of plasticity were carried out on 20 clays for ceramic bodies of Japan. These clays were classified into 5 categories according to their constituent minerals as (1) sedimentary kaolinite which contains organic materials and montmorillonite, (2) sedimentary kaolinite which contains organic materials but does not contain montmorillonite, (3) sedimentary kaolinite containing neither organic material nor montmorillonite, (4) hydrothermal mixed layer clay minerals containing kaolinite, and (5) hydrothermal sericite containing kaolinite. The mineralogical classification mentioned above is consistent with the classification based on the water content evaluated by the Pfefferkorn plasticity index, water retentivity, characteristic value of plastic clay (CV), ignition loss, specific surface area and thickness of water film on clay particles. Among them, the CV is exceedingly consistent with the mineralogical classification, and the value is considered to be more adequate to estimate the plasticity of ceramic bodies than any other values.

[Received July 29, 1983]

Key-words : Classification, Plastic clay, Ceramic body, Water content, Plasticity

\section{1. 緒 言}

陶磁器用环土 (粘土鉱物-水-長石, ケイ石等)の可塑 (塑 性変形) 現象を明らかにすることは, 古くて新しい問題 である．例えば，1950 年ころ学協会を中心に，可塑性 粘土の中心的役割を果たす諸特性解明に向けて集中的な
研究 ${ }^{1)}$ が行われたが，その粘土の可塑性現象に対しては 充分に解明されてない点が多い。この粘土特性解明に対 する要求は強く, その後も各専門分野で奥田 ${ }^{2)}$, 桑原 ${ }^{3)}$, 須藤 ${ }^{4)}$ らが，それぞれ優れた総説を行っている.

各陶業地における各粘土の可塑性に関する性格把握の 
ための一般法則はいまだ確立されておらず，経験的な判 断に頼っているのが現状である．著者らは，粘土の練土 の可塑性現象を数値的に表現するために，その可塑性の 支配要因を粘土鉱物と水素結合している水分と仮定し, 練土のような含水系の水分の中で, 強い結合水 (束縛水) の占める割合を見積もることにした：その束縛水（水素 結合水十層間水等）は温風乾燥器中で $40^{\circ} \sim 100^{\circ} \mathrm{C}$ の温 度範囲で逃げる水分量であると仮定した。この水分量と Pfefferkorn 試験法によって得た可塑含水率との比を可 塑特性值と呼び, 練土中の水分量の表示方法を提案し $た^{5)}$. 本研究では, この表示法を可塑性粘土の瀬戸産粘 土, 伊賀産粘土, 天草陶石系粘土, ボールクレー, 黒泥 に適用し, 練土中に含まれている粘土鉱物種の違いに よって，粘土種を分類できることを明らかにした。更に， この特性值と比表面積及び Ig. loss との関係について考 察した。

\section{2. 実験方法}

\section{1 供試粘土}

陶磁器用の白色可塑性粘土には, 主に堆積成因の力才 リナイト質粘土之熱水成因の陶石系粘土が使用されてい $3^{6}$. 本研究では, 堆積成因のカオリナイト質粘土 ${ }^{7}$ と して瀬戸・東濃地域で市販されている次の 12 種類を選 んだ．有機物を多く含んでいる伊賀地区の伊賀木節粘土 $(\mathrm{Ig})$, 瀬戸地区の本山木節粘土 $(\mathrm{KN}, \mathrm{Ks})^{8,9)}$, 枝下木 節粘土 $(\mathrm{Sh})$, 輸入した中国産黒泥 $(\mathrm{B})^{10), 11)}$ の水䇦物と 英国産ボールクレー (E) の原土，そして有機物含有量 が少ない蛙目粘土 ${ }^{12), 13)}$ として, 東濃地区の原蛙目粘土 $(\mathrm{GH})$, 瀬戸地区の本山黒 B 蛙目粘土 (GB), 本山白 B蛙目粘土 $(G W)$, 西山蛙目粘土 $(G N)$, 加仙蛙目粘 土 $(\mathrm{GK})$, 品川 $\mathrm{A}$ 級蛙目粘土 (Gsh) の水箕物を試料と した。 また，熱水成因の陶石系の粘土は次の 8 種類で, 出石陶石 $(\mathrm{Iz})^{14)}$, 大岾陶石 $(\mathrm{Oo})^{\left.{ }^{15}\right)}$, 松前陶石 $(\mathrm{Ma})$ の原土を実験室で水籍分級して細かい部分を回収したも のと, 天草陶石环土 $(\mathrm{Ab})$ 及びそれを水籍分級して得 た天草陶石粘土 $(\mathrm{Ac})^{16)}$, 村上粘土水籍物 ( $\mathrm{MA}, \mathrm{MB}$, MC) を試料とした。

これらの粘土の構成鉱物を調べるために，粉末 X 線回 折法（島津製作所製，自記 X 線回折装置 VD-2 型, $\mathrm{Cu} K \alpha$ 線, $\mathrm{Ni}$ フィルター), 赤外線吸収スペクトル法 (島 津製作所製, 赤外分光光度計 IR-430 $)^{177}$, 熱分析（理学 電機製, サーモフレックス・ミクロ TG-DTA ユニット) 及び Ig. loss（JIS-M 8854）を測定した。また，粘土 粉体の細かさを見積もるために， $\mathrm{N}_{2}$ ガス吸着による BET 法 (Carlo Erva 社製, Sorptomatic-1800) で比表 面積 $(S)$ を測定した。

\section{2 粘土の練土の調製法}

各陶業地の粘土乾粉 $500 \mathrm{~g}$ に対して, 200 300 g の純
水を添加してビニール袋中でよく練った後に封をし， $40^{\circ} \mathrm{C}$ の恒温槽内で 4 日間保持した。この間, 1 日に 1 回, ビニール袋の上から練った。恒温保持した試料は, 恒温 槽から取り出して室温で 1 日放置したものを練土として 使用した。

\section{3 練土の可塑性測定法}

粘土鉱物一水系の練土中の含水量と塑性変形量を表示 する方法は多く提案されている ${ }^{18)}$. その中でも，土質工 学関連の Atterberg 法とドイツの效業界で用いられてい る Pfefferkorn 法 ${ }^{19}$ の 2 方法がよく利用されている. 両 方法の相関関係は, 著者ら ${ }^{201}$ により明らかにされている.

Pfefferkorn 法は, 高さ $H_{0}=40 \mathrm{~mm}$ の練土の成形体 $(\phi$ $=33 \mathrm{~mm})$ を作り, 一定の高さ $(h=186 \mathrm{~mm})$ から $1192 \mathrm{~g}$ の円板を落下せしめ, この変形した高さ $H_{1}$ を測 定し, 変形比 $\left(H_{0} / H_{1}\right)=3.3$ における含水率で表示す る方法である. 本研究では, 成形体を変形させた後にそ の試料の一部をすばやくひょう量瓶に分取し，作業温度 下 (室温) での試料重量 $\left(W_{\mathrm{RT}}\right), 40^{\circ} \mathrm{C}$ の温風乾燥器中 で3〜4 日乾燥させて恒量になった試料重量 $\left(W_{40}\right)$, $100^{\circ} \mathrm{C}$ で 1 日乾燥させた後の試料重量 $\left(W_{100}\right)$ をそれぞ れ測定した. 変形比 $\left(H_{0} / H_{1}\right)=3.3$ における $100^{\circ} \mathrm{C}$ 乾 燥時の含水率を可塑含水率 (Pfefferkorn plasticity index $=\underline{\overline{P I}})$, また $40^{\circ} \mathrm{C}$ から $100^{\circ} \mathrm{C}$ の乾燥で逃げる水 分 (束縛水に相当すると考えられる水分)を保水率 (water retentivily $=W R)$, そして, 保水率と可塑含水率の比を 可塑特性值 (characteristic value of plastic clay $=C V$ ) と呼ぶことにし，下記の式で計算した。

$$
\begin{aligned}
P I & =\left\{\left(W_{\mathrm{RT}}-W_{100}\right) / W_{\mathrm{RT}}\right\} \times 100 \\
W R & =\left\{\left(W_{40}-W_{100}\right) / W_{\mathrm{RT}}\right\} \times 100 \\
C V & =(W R / P I) \times 100 \\
& =\left\{\left(W_{40}-W_{100}\right) /\left(W_{\mathrm{RT}}-W_{100}\right)\right\} \times 100
\end{aligned}
$$

なお, 含水率測定に使用した温風乾燥器の温度調節範 囲は, 各設定值の $\pm 2.0^{\circ} \mathrm{C}\left(40^{\circ} \mathrm{C}\right), \pm 3.5^{\circ} \mathrm{C}\left(100^{\circ} \mathrm{C}\right)$ であった。

また，得られた各数值から，Ig. loss，比表面積 $(S)$, $C V, P I, W R$ 間の相関係数を求めて相互の関係を検討 した.

\section{3. 実験結果}

\section{1 粘土の構成鉱物}

粘土の構成鉱物は，木節粘土，蛙目粘土類ではカオリ ナイトが主鉱物であるが，陶石類ではセリサイト又は白 雲母, トスダイトが主鉱物であった。そのほかに長石, 石英及び微量のイライトが含まれており，主な粘土鉱物 を表 1 に示し，粘土鉱物種間の相対量は不等記号で表示 した.

堆積成因のカオリナイト質粘土では，カオリナイトと 有機物（腐植）が多く含有されていて，粉末 X線回折か 
Table 1. Constituent clay minerals and organic material of each sample.

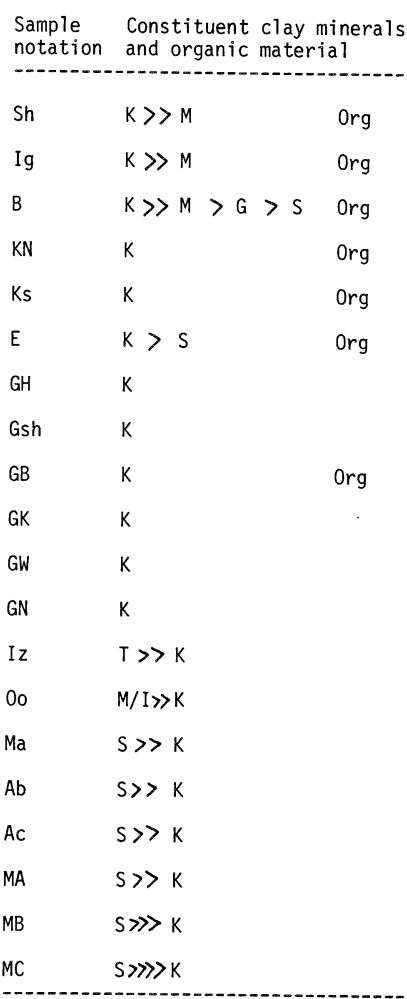

K:kaolinite, M:montmorillonite G:gibbsite, S:sericite

$T$ : tosudite, M/I:montmorillonite/

illite mixed layer clay mineral, Org:organic material

らモンモリロナイトの認められた（Sh), (Ig), (B) の 木節粘土系グループ(1)，モンモリロナイトがほとんど認 められなかった $(\mathrm{KN}),(\mathrm{Ks}),(\mathrm{E})$ の木節粘土系グル一 プ(2), モンモリロナイト，有機物ともにほとんどない $(\mathrm{GH}),(\mathrm{GB}),(\mathrm{GW}),(\mathrm{GN}),(\mathrm{GK}),(\mathrm{Gsh})$ の蛙目 粘土系グループ(3)，の三つに区分できた。この中でボー ルクレー（E) にはセリサイト, 黒泥 (B) にはギプサ イトが混在した。

熱水成因の陶石系粘土では，混合層粘土が主体でカ才 リナイトを少量含む ( $\mathrm{Iz}),(\mathrm{Oo})$ のグループ(4), セリ サイト (又は白雲母) が主体で少量のカオリナイトを含 有する $(\mathrm{Ma}),(\mathrm{Ab}),(\mathrm{Ac}),(\mathrm{MA}),(\mathrm{MB}),(\mathrm{MC})$ のグループ(5)，の二つに区分できた．この中で，村上粘 土はカオリナイトの含有量に差があり, (MA), (MB), ( $\mathrm{MC})$ の順に少なかった. また, 天草陶石粘土 (Ac) は, もとの天草陶石环土 $(\mathrm{Ab})$ に比べて石英の含有量は少 なく，比表面積は大きくなったが，カオリナイトとセリ サイトの含有割合にはほとんど差はなかった。

3.2 粘土粉体の比表面積 ( $\boldsymbol{S}$ ) と Ig. loss カオリナイトとセリサイトの Ig. loss の理論值は,
Table 2. Parameters of plasticity for 20 samples.

\begin{tabular}{|c|c|c|c|c|c|c|c|}
\hline Sample & Ig. loss & $\left(\mathrm{m}^{2} / \mathrm{g}\right)$ & $\begin{array}{l}\text { PI } \\
(\%)\end{array}$ & $\begin{array}{l}\text { WR } \\
(\%)\end{array}$ & $\begin{array}{l}\mathrm{CV} \\
(\%)\end{array}$ & $\begin{array}{l}H z i \\
(A)\end{array}$ & $\begin{array}{l}\begin{array}{l}H 40 \\
(\AA)\end{array}\end{array}$ \\
\hline B & 14.87 & 34.9 & 35.2 & 1.51 & 4.28 & 155 & 6.68 \\
\hline Sh & 14.23 & 47.7 & 36.9 & 1.80 & 4.88 & 122 & 5.97 \\
\hline Ig & 13.10 & 29.5 & 30.3 & 1.43 & 4.72 & 147 & 6.95 \\
\hline $\mathrm{E}$ & 10.30 & 27.8 & 28.4 & 0.98 & 3.46 & 142 & 4.91 \\
\hline KN & 15.34 & 39.5 & 35.3 & 1.29 & 3.65 & 137 & 5.05 \\
\hline Ks & 15.43 & 32.6 & 33.2 & 1.16 & 3.49 & 152 & 5.32 \\
\hline GH & 11.64 & 37.0 & 31.9 & 1.34 & 4.20 & 126 & 5.31 \\
\hline Gsh & 12.50 & 37.1 & 32.8 & 1.38 & 4.20 & 131 & 5.53 \\
\hline GB & 13.47 & 42.3 & 32.7 & 1.34 & 4.08 & 115 & 4.71 \\
\hline GK & 11.96 & 32.9 & 32.9 & 1.28 & 3.89 & 149 & 5.79 \\
\hline GW & 13.05 & 40.8 & 34.5 & 1.22 & 3.54 & 129 & 4.56 \\
\hline GN & 13.84 & 43.8 & 33.8 & 1.22 & 3.59 & 117 & 4.21 \\
\hline Iz & 3.73 & 11.3 & 23.4 & 0.59 & 2.51 & 270 & 6.82 \\
\hline 00 & 2.86 & 13.6 & 26.7 & 0.59 & 2.21 & 268 & 5.91 \\
\hline Ma & 5.17 & 34.6 & 39.7 & 0.63 & 1.60 & 190 & 3.00 \\
\hline$A b$ & 3.57 & 11.6 & 23.7 & 0.31 & 1.32 & 268 & 3.49 \\
\hline $\mathrm{Ac}$ & 6.92 & 29.2 & 37.0 & 0.49 & 1.32 & 201 & 2.66 \\
\hline MA & 3.34 & 22.2 & 26.2 & 0.49 & 1.86 & 159 & $2: 99$ \\
\hline MB & 3.30 & 19.0 & 26.3 & 0.42 & 1.58 & 187 & 3.01 \\
\hline MC & 2.87 & 15.1 & 27.8 & 0.37 & 1.34 & 255 & 3.38 \\
\hline
\end{tabular}

S:specific surface area, PI:Pfefferkorn plasticity index, WR: water retentivity, CV:characteristic value of plastic clay, Hpi:thickness of water film on clay particle at PI, $\mathrm{H} 40$ : thickness of water film on clay particle at $40^{\circ} \mathrm{C}$.

$14.0 \%, 4.5 \%$ であり，構成鉱物種の差異によって粘土 の Ig. loss は大きく左右されるが, 含有量によっても影 響される.試料粘土の Ig. loss は, 水簸分級の度合によっ て多少の差は生じているが, 総体的に堆積成因のカオリ ナイト質粘土では $10.3 \sim 14.8 \%$ の範囲にあうてカオリ ナイトの理論值 $14.0 \%$ に近く, 陶石系粘土では 2.86 $6.90 \%$ とセリサイトの理論值 $4.5 \%$ 付近に分布した（表 2 ).

比表面積 $(S)$ は，粘土鉱物粒子の細かさとその含有 量によって左右される. このため比表面積 $(S)$ は, Ig. loss に比較して水箕分級の度合の差が現れやすい数 值である. 堆積成因のカオリナイト質粘土のそれは $27.8 \sim 48.8 \mathrm{~m}^{2} / \mathrm{g}$ であり, 陶石系粘土では $11.3 \sim 34.6$ $\mathrm{m}^{2} / \mathrm{g}$ であった. しかし, 実験室で水簸した試料 $(\mathrm{Ma})$, （Ac）を除外すれば，陶石系粘土の比表面積 $(S)$ は 11. 3 $22.2 \mathrm{~m}^{2} / \mathrm{g}$ となり，堆積成因のカオリナイト質粘 土に比べて細かい粒子が少ないのが特徴であった。

比表面積 $(S)$ と Ig. loss の相関係数 $R$ は 0.851 と 高い值を示した. 更に, 各データの分布状態は図 1 のよ うに陶石系粘土と堆積成因のカオリナイト質粘土に区分 でき，木節粘土系は有機物含有量が多いため, 蛙目粘土 系よりも Ig. loss の多い側に分布する. 


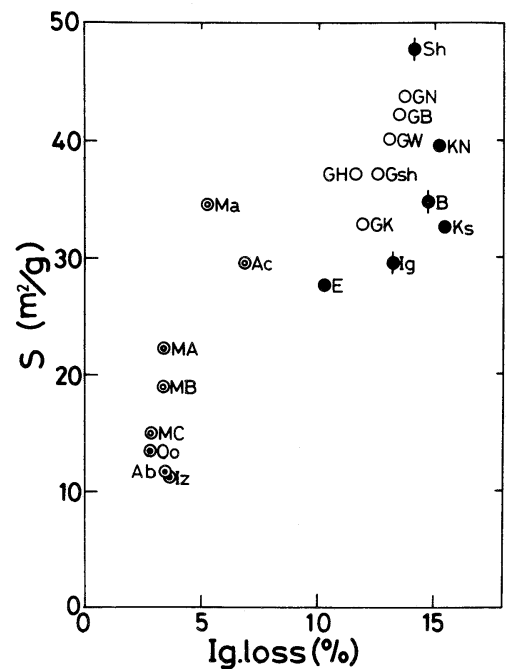

Fig. 1. Relation between specific surface area $(S)$, and ignition loss of each clay.

$R$ : Correlation coefficient, Open circle : Sedimentaly kaolinitic clay without organic material nor montmorillonite, Solid circle: Sedimentaly kaolinitic clay with organic material, Slashed solid circle: Sedimentaly kaolinitic clay with montmorillonite and orgamic materials, Concentric double circle : Hydrothermal origin sericitic clay with kaolinite, Circle with dott in center: Mixed layer clay minerals with kaolinite

\section{3 含水系の測定結果}

\section{3.1 可塑含水率 $(P I)$}

可塑含水率 $(P I)$ は, 堆積成因のカオリナイト質粘 土では 28.4 36.9\% を示し. 熱水成因のセリサイト質 (陶石系) 粘土では 23.4 - 39.7\% の範囲の值を示した. しかし，陶石系粘土では実験室で水簯した試料 $(\mathrm{Ma})$ と $(\mathrm{Ac})$ を除けば $P I$ は $23.4 \sim 27.8 \%$ となり, PI の違 いから堆積成因のカオリナイト質粘土と陶石系粘土の二 つに区分できそうである. 比表面積 $(S)$ と $P I$ の相関 係数 $R$ は 0.830 と高く, Ig. loss と $\overline{P I}$ では $R=0.622$ と低い値を示した。

比表面積 $(S)$ とPI の関係は図2のようで, この分 布状態加陶石系粘土, 木節粘土系, 蛙目粘土系の 3 帯 に区分できることが分る．PI の大きさの違いから，同 一の塑性変形量を得るには, 蛙目粘土 系粘土の関係で多くの水分を必要とすることが分る.ま た, 試料 (MA), (MB), (MC) の関係は, カオリナ イトの含有量が増加するに従って PI が低下する傾向に あることが推定される.

\subsection{2 保水率 $(W R)$}

保水率 $(W R)$ は, 堆積成因のカオリナイト質粘土で は $0.98 \sim 1.80 \%$ であり，陶石系粘土では $0.31 \sim 0.64 \%$ で両者は明確に区分できる. 比表面積 $(S)$ と WR の相 関係数は $R=0.832$ であり, 両者の関係を図 3 に示した。

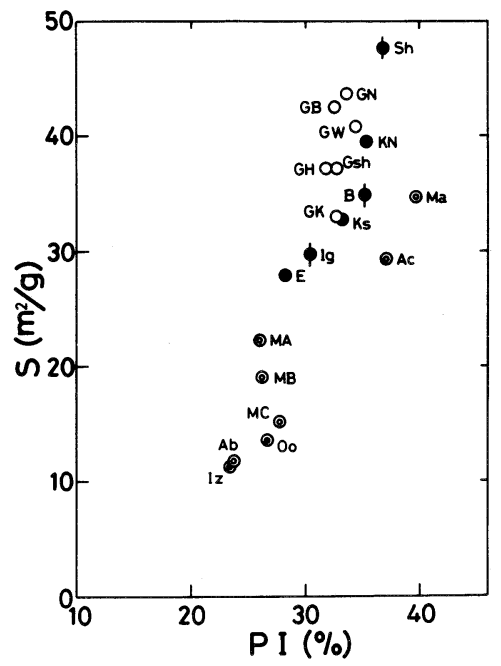

Fig. 2. Relation between specific surface area $(S)$ and Pfefferkorn plasticity index $(P I)$.

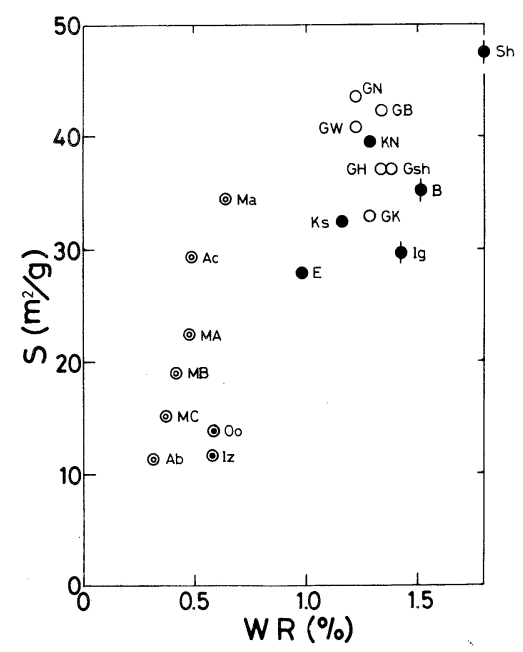

Fig. 3. Relation between specific surface area $(S)$ and water retentivity $(W R)$.

この図から，堆積成因のカオリナイト質粘土では，モン モリロナイトを含む木節粘土グループ(1)とモンモリロナ イトをほとんど含まない木節粘土グループ(2)及び蛙目粘 土グループ(3の三つに区分でき, 一方, 陶石系粘土が混 合層粘土グループ(4)とセリサイト質粘土グループ(5)の二 つに区分できることが分る.

WR の大きさの関係は, グループ(1)>(2), (3)> (4)> (5)関係にあり, 含有粘土鉱物種の差が現れている.し かし, 図 3 のように各粘土グループの測定值の帯状分布 状態は比表面積 $(S)$ に対して傾斜しており, $W R$ と比 表面積 $(S)$ との相関も若干存在することを示している.

\subsection{3 可塑特性值 $(C V)$}

可塑特性値 $(C V)$ は, 含有粘土鉱物種による分類と ほぼ対応した結果が得られた（表 2 ). 堆積成因のカオ 


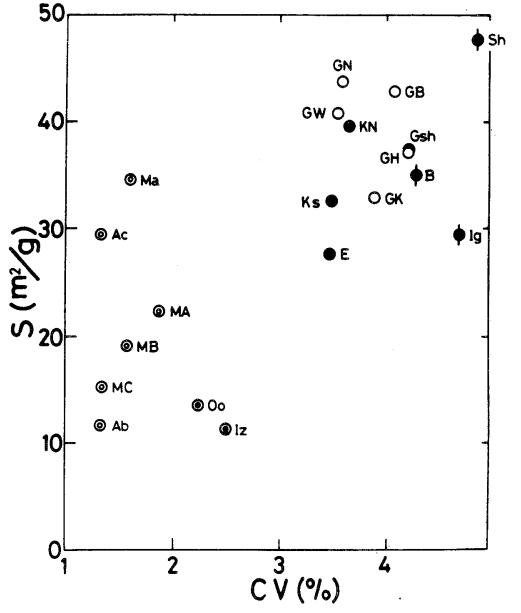

Fig. 4. Relation between specific surface area $(S)$ and characteristic value of plasticity $(C V)$.

リナイト質粘土の $C V$ は, 3. 64〜 4. 88\% の範囲になり, 可塑特性值 $(C V)$ からも保水率 $(W R)$ で区分したよ うなグループ(1), (2), (3)に分けられ, 陶石系粘土の $C V$ は $1.33 \sim 2.51 \%$ で, やはりグループ(4), (5)に分類でき ることが分った。

可塑特性値 $(C V)$ と比表面積 $(S)$ との相関係数は, $R=0.719$ で相関性はあるが，両者の測定值を図 4 でみ ると, 各粘土グループと比表面積 $(S)$ とには相関性は なく, 試料全体としては相関があることを示している. しかし, 試料 (MA), (MB), (MC) の間では, カ才 リンの含有量の変化に対応して比表面積 $(S)$ と $C V$ と に相関があるが, 試料 $(\mathrm{Ab})$ とそれを実験室で水簯し た試料 $(\mathrm{Ac})$ の両者には, $C V$ の值に変化はなく, 比 表面積 $(S)$ のみに差があった.

3.4 比表面積（S） 及び Ig. loss と含水系の関係 各測定項目 $(P I, W R, C V, I g$. loss, $S)$ 間の相関 係数を求めて表 3 に示した. Ig. loss は $P I$ とは $R=$ 0.622 と低い値を示したが, 他の $W R, C V, S$ とは $R$ $=0.8$ 以上であった. 比表面積 $(S)$ は $C V$ とは $R=$ 0.719 を示したが, 他の $P I, W R$, Ig. loss とは $R=$ 0.8 以上であった. $P I$ は $S$ と強い相関はあったが, 他 の測定項目との間のそれは弱かった。

\section{4. 考察}

実験結果には多くの情報を含んでいるが，ここでは可

Table 3. Matrix of correlation between five parameters.

\begin{tabular}{lccccc} 
& Ig. loss & S & PI & WR & CV \\
\hline Ig.10ss & - & 0.851 & 0.622 & 0.925 & 0.880 \\
S & 0.851 & - & 0.830 & 0.832 & 0.719 \\
PI & 0.622 & 0.830 & - & 0.566 & 0.388 \\
WR & 0.925 & 0.832 & 0.566 & - & 0.974 \\
CV & 0.880 & 0.719 & 0.388 & 0.974 & -
\end{tabular}

塑特性值 $(C V)$ により可塑性粘土の分類が可能になっ た原因について考察する.

$C V$ の定義に $S$ を導入して変形すると,

$$
\frac{C V}{100}=\frac{W R}{P I}=\frac{\left(\frac{W_{40}-W_{100}}{W_{\mathrm{RT}}}\right) / S}{\left(\frac{W_{\mathrm{RT}}-W_{100}}{W_{\mathrm{RT}}}\right) / S}=\frac{\left(W_{40}-W_{100}\right) / S}{\left(W_{\mathrm{RT}}-W_{100}\right) / S}
$$

になり, $C V$ は塑性変形時の室温から $100^{\circ} \mathrm{C}$ 乾燥まで の試料の水分重量と $40^{\circ} \mathrm{C}$ から $100^{\circ} \mathrm{C}$ 乾燥までの水分重 量をそれぞれの比表面積で割った值の比，つまり試料の 室温時と $40^{\circ} \mathrm{C}$ 乾燥時の水膜の厚さの比であることが分 $ろ^{21)}$.これは粘土鉱物種の表面と結合している水分量を 異なる 2 点の温度で測り, 両者の水分量の比で表してい ることになる. 各々の粘土の $C V$ は，粘土を構成する 粘土鉱物種の表面状態に左右されていると考えられる. 例えば, 粘土の練土中に 2 種以上の粘土鉱物種が存在す る場合, それらの粘土鉱物の含有割合が変動しないとき は $C V$ は一定となるだろう。これに対してそれらの含 有割合が変わると $C V$ の值も変動すると考えられる. 前者の例では, 試料 $(\mathrm{Ab})$ と $(\mathrm{Ac})$ の関係にみられる ように, 比表面積 $(S)$ に差があっても $C V$ が一定になっ ていること, 後者の例では, 試料 (MA), (MB), (MC) のようにカオリナイトの含有量が少なくなるに従って $C V$ の值が低下することからも証明される.このような 原因によって, 表 1 及び表 2 のように $C V$ の值に基づ いた各々の粘土の配列順が, 構成粘土鉱物種に対応した ものになったと考えられる.

一方，従来からよく可塑性の指標の一つとして用いら れる粘土粒子表面の水膜の厚さ $(H)^{2)}$ は, $P I, W R$, $C V$ 及び $S$ を用いて以下のように表すことができる.

可塑性試験時（室温）における可塑含水率に基づいた 粘土粒子表面の水膜の厚さ $\left(H_{\mathrm{PI}}\right)$ は,

$$
H_{\mathrm{pI}}=P I /\{(100-P I) S\}
$$

であり, $40^{\circ} \mathrm{C}$ 乾燥のときの水膜の厚さ $\left(H_{40}\right)$ は,

$$
H_{40}=W R \cdot C V /\{100(C V-W R) S\}
$$

のように表される．上式を用いて計算した水膜の厚さ $H_{\mathrm{PI}}, H_{40}$ を表 2 に示す. $40^{\circ} \mathrm{C}$ 乾燥時の水膜の厚さ $\left(H_{40}\right)$ は，有機物の多い粘土グループ(1)，(2)の場合は $5.0 \pm$ $0.5 \AA$, 蛙目粘土グループ(3)の場合は約 $4.5 \pm 0.5 \AA$, 陶 石系で混合層粘土グループ(4)では $5.5 \AA$ 以上，セリサイ ト系のグループ(5では $3.0 \pm 0.5 \dot{A}$ となり, 大きな区分 ができ, ほぼ可塑性の順序と一致している. しかし, 混 合物の多い粘土と少ない粘土（例えば $\mathrm{Ab} \leftrightarrow \mathrm{Ac}$, $\mathrm{MA} \leftrightarrow \mathrm{MB} \leftrightarrow \mathrm{MC})$ とを比較すると，いわゆる可塑性の 良否の順序と逆転しており, 水膜の厚さからは単純に説 明できない，この原因は，比表面積 $(S)$ の少ないもの を粘土に混合した場合, 粘土の比表面積 $(S)$ の值は比 較的に減少するが, 粘土鉱物表面と結合した水の量は, 
比表面積の大きい粘土鉱物の含有量とその種に強く支配 されており,あまり変化しないことになる.結果的には, 比表面積の少ない粘土の系（混合物の多い粘土）の方が 見掛け上，水膜が厚いかのように算出されてくる. つま り, 純粋な粘土鉱物から構成されていない一般の混合系 の粘土の場合, この水膜の厚さによる可塑性の議論はで きないと言える.

これに比べて上述の $C V$ 値は, 比表面積で分子, 分 母を除した值の比に相当し, 比表面積の効果を打ち消し ているために，一般の粘土のような混合系に適用できる 有効な指標であると言える.

\section{5. まとめ}

（1）各種粘土間で水簸分級の度合に違いがあって も, Ig. loss-比表面積 $(S)$ の関係から, 粘土は堆積成 因のカオリナイト質粘土と熱水成因の陶石系粘土に大別 できることが分った.

(2) 可塑含水率 $(P I)$-比表面積 $(S)$ の関係から, 堆積成因のカオリナイト質粘土を蛙目粘土と木節粘土に 区分でき，陶石系粘土と併せて三つに区分できた.

（3）保水率 $(W R)$-比表面積 $(S)$ の関係から, 陶 石系粘土がセりサイト系粘土と混合層系粘土に区分で き, 堆積成因のカオリナイト質粘土は, モンモリロナイ トを含む木節粘土系とモンモリロナイトをほとんど含ま ない木節粘土系及び蛙目粘土系の 5 グループに区分でき た.

(4) 可塑特性値 $(C V)$-比表面積 $(S)$ の関係からは, 保水率 $(W R)$-比表面積 $(S)$ からの区分よりも更に明 確に区分でき，それぞれの粘土グループの水籍度合（比 表面積 $(S)$ として間接的に表現される）に関係なく可 塑特性値 $(C V)$ が与えられる.

( 5 ) 可塑特性值 $(C V)$ による粘土グループの分類 とX線回折等から調べた構成鉱物種の組み合わせからの 分類がよく合致した.
( 6 ) 可塑特性值 $(C V)$ に上る可塑性粘土の評価法 は, 従来使用されてきた水膜の厚さからのものよりも, はるかに広範な粘土に適用できることが明らかになっ た。

謝 辞 本研究に当たり, 有益な御助言を頂いた名古屋工業 技術試験所第 6 部第 3 課長・金岡繁人博士に感謝すると同時に, Pfefferkorn 試験等を手伝って頂いた丸仙陶器原料（株）牧 繁 伸氏, 大沢耐火（株）石川正臣氏, 中島碍子（株）熊沢重憲氏, 石川製陶（株）中川定信氏に感謝します。

\section{文献}

1)素木洋一, “窯業原料第 4 集”, 硯学書房 (1952) p. 99-106.

2) 奥田 進, 粘土科学, 8, 14-23 (1968).

3) 桑原 徹, 粘土科学, 10, 12-28 (1970).

4) 須藤清次, 粘土科学, 8, 8-13 (1968).

5）芝崎靖雄, 前田武久, 金岡繁人, 昭和 54 年窯業協会年会 講演予稿集, 62 (1979).

6) N. Fujii, Y. Togashi and T. Igarashi, “An Outline of Kaolin, Pyrophyllite and Sericite Clay Deposits in Japan", Geological Survey of Japan (1976).

7) 藤井紀之, 粘土科学, 18, 90-104 (1978).

8）芝崎靖雄, 前田武久, 金岡繁人, 昭和 53 年窯業協会年会 講演予稿集, 37 (1978).

9）芝崎靖雄, 前田武久, 中原佳子, 昭和 53 年窯業協会年会 講演予稿集, 38 (1978).

10）前田武久, 芝崎靖雄, 山田武雄, 昭和 55 年窯業協会年会 講演予稿集, 73 (1980).

11）前田武久, 芝崎靖雄, 山田武雄, 昭和 55 年窯業協会年会 講演予稿集, 74 (1980).

12）前田武久, 芝崎靖雄, 金岡繁人, 昭和 54 年窯業協会年会 講演予稿集, 61 (1979).

13）前田武久, 芝崎靖雄, 昭和 54 年窯業協会年会講演予稿集, 60 (1979).

14）金岡繁人, 加藤悦三, 窯協, 89, 119-23 (1981).

15）種村光郎, 堀内恵彦, 地調月報, 9, 247-61 (1958).

16）前田武久, 芝崎靖雄, 金岡繁人, 昭和 53 年窑業協会年会 講演予稿集, 34 (1978).

17）加藤悦三, 金岡繁人, 稲垣貞子, 名工試報告, 26, 203-09 (1977).

18) A. Atterberg, Inter. Mitt. Bodenk., 1, 4-37 (1911).

19) K. Pfefferkorn, Sprechsaal, 57, 297-99 (1924).

20）金岡繁人, 芝崎靖雄, 前田武久, 渡村信治, 照屋善義, 神野好孝, 粘土科学, 21, 37-46 (1981).

21）芝崎靖雄, 金岡繁人, 前田武久, 渡村信治, 水田博之, 粉体および粉末治金，27，256-60（1980）。 